\begin{tabular}{|c|c|c|c|}
\hline KULTURA & $\begin{array}{l}\text { POLSKA } \\
\text { KOMITET } \\
\text { INSTYTU }\end{array}$ & $\begin{array}{l}\text { AKADEMIA NAUK } \\
\text { SOCJOLOGII } \\
\text { T STUDIÓW POLITYCZNYCH }\end{array}$ & ISSN 0023-5172 \\
\hline S & 2016, nr 1 & MIĘDZY KULTURAMI: SZKICE I & NOTATKI \\
\hline
\end{tabular}

MAJA BIERNACKA

Uniwersytet $w$ Biatymstoku

\title{
PARADOKS POLITYKI TOŻSAMOŚCIOWEJ W HISZPANII AMBIWALENCJA KOŚCIOŁA WOBEC ODMIENNOŚCI JĘZYKOWEJ BASKÓW ZA RZĄDÓW FRANCO
}

Odmienność językowa Basków przez wieki była kluczowym czynnikiem pozwalającym podtrzymywać hermetyczny charakter ich wspólnot oraz siłę lokalnych więzi społecznych. Do dziś ich rdzenny język, którego nazwa własna to euskera ${ }^{1}$, stanowi zasadniczy wyróżnik i podstawę poczucia odrębności etnicznej. Taki stan rzeczy utrzymuje się w Hiszpanii wbrew długotrwałym zabiegom państwotwórczym, prowadzonym zarówno wtedy gdy była ona potęgą imperialną, jak i później, to jest za czasów mającej podwaliny w epoce modernizacji idei jednolitego narodu hiszpańskiego - nota bene niezbyt fortunnej w realizacji i praktyce społecznej. Idea ta obowiązywała w okresie frankistowskim i była formalnie wspierana autorytetem Kościoła.

Rola Kościoła w warunkach różnorodności etnicznej obarczona była jednak wewnętrznymi sprzecznościami, co nie jest faktem powszechnie znanym. Próba bardziej analitycznego spojrzenia, którą zamierzam podjąć, pozwala wyjść poza fasadową wizję instytucji religijnej ściśle współpracującej z władzami frankistowskiej Hiszpanii. Mowa o Kościele sensu lato - to jest obejmującym nie tylko instytucję i kler, ale również wspólnotę wiary. Tak właśnie rozumiany Kościół działał bowiem zarówno na korzyść, jak i przeciwko realizacji idei narodowej w Hiszpanii. Rozważania na temat tego zjawiska ograniczam do okresu sprawowania władzy przez Francisco Franco Bahamonde. Jego rządy trwały długo — przez trzy i pół dekady, aż do śmierci przywódcy w listopadzie $1975 \mathrm{roku}$,

\section{Adres do korespondencji: mmbiernacka@tlen.pl}

${ }^{1}$ Ew. euskara, eskuara, eskuora czy üskara. Istnieją różne dialekty w obrębie tego języka, stąd oboczność jego nazwy własnej. 
która położyła kres całej epoce w państwowości hiszpańskiej i naznaczyła początek transformacji systemowej. Podejmuję analizę socjologiczną, a kontekst historyczny frankizmu stanowi przede wszystkim pretekst do pokazania fundamentalnego aspektu „kwestii baskijskiej”, jaką jest odrębność języka oraz konsekwentne działania w celu jego zachowania jako sposób na ochronę ciągłości etnicznej. Pokazuję, że z jednej strony Kościół stanowił podporę moralną hiszpańskiego centralizmu, wyobrażeń o jednym narodzie i symbolicznie legitymizował działania na rzecz asymilacji nieprzystających doń mniejszości. $Z$ drugiej strony zaś - wbrew ideałom unifikacji narodowej - na poziomie lokalnym służył w Kraju Basków podtrzymaniu odrębności i zachowaniu ciągłości etnicznej. Znajdowało to wyraz we współdziałaniu lokalnego kleru na rzecz nauki euskera. Podstawowa rozpatrywana tu teza głosi, że Kościół rzymskokatolicki w Hiszpanii pełnił w ten sposób ambiwalentną rolę wobec baskijskiej odmienności.

\section{JĘZYK JAKO WYRÓŻNIK BASKIJSKIEJ ODRĘBNOŚCI}

Euskera jako jedyny spośród - tak zwanych zgodnie z obowiązującą dziś Konstytucją - języków hiszpańskich nie należy nie tylko do tej samej grupy językowej co kastylijski², ale i do żadnej innej występującej we współczesnej Europie, co sprawia, że jest dla Hiszpanów, którzy się go nie uczyli, całkowicie niezrozumiały. Współcześnie należy on w Hiszpanii do języków urzędowych, przyjętych na poziomie poszczególnych wspólnot autonomicznych obok języka kastylijskiego, który z kolei jest jedynym językiem obowiązującym na poziomie ogólnopaństwowym. Taki status formalny ma euskera od czasów transformacji systemowej po śmierci generała Francisco Franco, a bardziej precyzyjnie wraz z ratyfikacją Konstytucji i uchwalonego rok później, a obowiązującego do dziś Statutu Autonomii Kraju Basków, zwanego również Statutem z Guerniki. Konstytucja, uchwalona w 1978 roku, przewiduje tę możliwość prawną $\mathrm{w}$ art. $3.2 \mathrm{w}$ odniesieniu do pozostałych języków hiszpańskich ${ }^{3}$, jednak bez doprecyzowania, jakich języków się to tyczy. Na etapie systemowego kształtowania się nowej państwowości kraju zabieg ów dał wolną rękę poszczególnych wspólnotom autonomicznym, dopuszczając konstruowanie statutów albo z przyjęciem kastylijskiego jako jedynego oficjalnego języka, albo z uwzględnieniem ich odmienności językowej, jak choćby w Autonomii Kraju Basków.

\footnotetext{
2 Ze względu na specyfikę tematu rygorystycznie używam nazwy „język kastylijski”, a nie „hiszpański”. Ten właśnie język jest podstawowy dla państwowości i jako taki - w ślad za Konstytucją (art. 3.1) - jest nazywany ję zyki e m his z pańskim. Konstytucja nie ogranicza jednak tego określenia do kastylijskiego, mianowicie w tym samym artykule ustawy zasadniczej (art. 3.2) pojawia się określenie pozostałe języki hiszpańskie (patrz dalejw tekście, dotyczy tego następny przypis).

$3 \mathrm{~W}$ wersji oryginalnej ustawy zasadniczej Hiszpanii są to: las demás lenguas españolas (art. 3.2 Konstytucji).
} 
W porównaniu do katalońskiego czy galicyjskiego, które należą do tej samej grupy językowej co kastylijski i znając go można relatywnie szybko je opanować, język Basków pozostaje hermetyczny. W żadnym razie nie zmieniają tego pojedyncze zapożyczenia leksykalne, dotyczące choćby administracji publicznej, nauki czy nowych technologii, pojawiające się w języku wraz z rozwojem cywilizacyjnym. Wyjątkowość euskera jest tym bardziej znacząca, że jest uznany za jedyny współcześnie używany w Europie Zachodniej język praindoeuropejski (Trask 1997, s. 35; Echeverria 2007, s. 181; Ibarretxe, Larrea 2012, s. 179; por. Haasse 2011, s. 209). Warto podkreślić, że ma on charakter endemiczny i jego znajomość jest wśród ludności zamieszkującej Kraj Basków ograniczona ${ }^{4}$, między innymi ze względów historycznych, o których mowa dalej. Podczas gdy nauka języka kastylijskiego jest w dzisiejszej Hiszpanii konstytucyjnym obowiązkiem obywateli, nauka euskera na poziomie Autonomii jest zagwarantowana prawem i realizowana $\mathrm{w}$ praktyce, czemu służy rozwinięta infrastruktura placówek zajmujących się działalnością edukacyjną, zarówno publicznych, jak i prywatnych. Przez większość okresu obowiązywania systemu frankistowskiego istnienie tego języka w żadnym razie nie znajdowało miejsca $\mathrm{w}$ oficjalnym imaginarium ani $\mathrm{w}$ ramach systemowych i było traktowane jako rysa na obliczu Hiszpanii.

Dziś właśnie znajomość euskera stanowi podstawowy wyróżnik baskijskości i sposób jej uwierzytelnienia w codziennym życiu społecznym (por. Kasmir 1996, s. 119; Conversi 1997, s. 44; Trask 1997, s. 322; Azurmendi, Bachoc, Zabaleta 2001, s. 257-258; Mitxelena 2001; Amorrortu 2003; Zallo 2006, s. 129; Gatti 2007, s. xv, 75; Mallea-Olaetxe 2008, s. 213). Należy podkreślić, że wyróżnikiem takim $\mathrm{w}$ żadnym razie nie jest skłonność do stosowania przemocy - jak można byłoby wnioskować na podstawie od lat powielanych przez codzienną prasę obrazów każdego spowodowanego przez ETA ${ }^{5}$ terrorystycz-

4 Dane dotyczące znajomości euskera są zbierane podczas badań sondażowych o nazwie Encuesta Sociolingüística. Zgodnie $z$ najnowszymi danymi, to jest z piątej edycji tego sondażu, uzyskanymi w 2011 roku, a opublikowanymi w 2013 roku (V ES 2013, ryc. 4, s. 66), około 32\%, czyli nieco mniej niż co trzeci mieszkaniec Autonomii Kraju Basków, jest w stanie posługiwać się euskera, obok kastylijskiego, w poprzedniej — przeprowadzonej pięć lat wcześniej — edycji badań odsetek ten był nieznacznie niższy i wynosił 30,1\% (IV ES 2008, ryc. 3, s. 18). Część respondentów deklarowała, że ich dwujęzyczność ma charakter pasywny. W 2011 roku w taki sposób oceniło swe umiejętności językowe 17,4\%, a w 2006 roku - 18,3\%. Nieco ponad połowa respondentów, tj.50,6\%, przyznała w 2011 roku, że nie zna euskera. W 2006 roku wskaźnik ten wyniósł $51,5 \%$. Podaję dane zagregowane dotyczące przynależnej do państwa hiszpańskiego Autonomii Kraju Basków. Odrębna pozostaje kwestia Nawarry, w której poziom tożsamości baskijskiej oraz znajomości euskera jest jeszcze niższy, podobnie jak w części historycznej krainy Baskonii leżącej na terytorium Francji, przez Basków zwanej Iparralde. Niestety nie ma możliwości porównania tych danych do okresu sprawowania władzy przez generała Franco. Podczas gdy kwestia kompetencji językowych w euskera jest współcześnie monitorowana, dane takie ze zrozumiałych względów nie były w Hiszpanii za czasów Franco zbierane.

5 Ten skrót jest rozpoznawany powszechnie, dlatego stosuję go w tekście. Pełna nazwa to Euskadi Ta Askatasuna [Baskonia i Wolność]. 
nego incydentu. Ponieważ działania tej organizacji nieodmiennie okazywały się bardziej atrakcyjne medialnie, w kulturze popularnej pierwszym skojarzeniem z Baskami pozostaje raczej terroryzm niż euskera. Paramilitarne akcje ETA sprowadzały jednak przede wszystkim krzywdę ludzką - ofiarą krwawych działań padały nie tylko osoby namierzone przez terrorystów, ale i postronna ludność cywilna. Aż do ostatniego, dotychczas dotrzymywanego, zawieszenia broni z 2011 roku generowało to potępienie zdecydowanej większości społeczeństwa Hiszpanii, a również coraz bardziej negatywne oceny wśród samych Basków ${ }^{6}$. Tymczasem konsekwentne działania na rzecz zachowania odrębności baskijskiej mają charakter zdecydowanie bardziej subtelny i podejmowane są na poziomie życia codziennego. Nauka języka przodków - w przeciwieństwie do działań ETA - stanowi powszechne, a do tego pokojowe narzędzie zachowania i demonstrowania baskijskiej odrębności.

Działania na rzecz zachowania euskera na poziomie instytucjonalnym oraz indywidualnym są nie tylko bardziej wyrafinowaną, ale też wbrew pozorom bardziej skuteczną formą walki o zachowanie odrębności etnicznej. To przede wszystkim język zapewnia ciągłość kultury oraz świadomości zbiorowej Basków. Chodzi zwłaszcza o działania mające na celu podtrzymanie dziedzictwa językowego, a wraz z nimi możliwość tworzenia, popularyzacji oraz międzypokoleniowej transmisji kultury tworzonej w tym języku. Przez wieki euskera nie był językiem władzy, uważano go wręcz za nieodpowiedni do wyrafinowanego symbolicznie przekazu. Traktowano jako pośledni względem kastylijskiego i poddawano hiszpańskiej polityce unifikacji narodowo-etnicznej. Jednak językowa odmienność Basków nie została zniwelowana również za czasów trwającego kilka dekad reżimu generała Franco, gdy idea jednego narodu była w państwie Hiszpanii nadrzędna, a odstępstwa od niej wyrażane w sferze publicznej przez większość trwania systemu podlegały represjom.

\section{EUSKERA A POLITYKA ZA CZASÓW FRANCO}

Przez większość trwania reżimu frankistowskiego odmienność językowa Basków stanowiła element niewygodny politycznie i była pozbawiona umocowania legislacyjnego. Działo się tak ze względu na formę państwowości Hisz-

\footnotetext{
${ }^{6}$ Zgodnie $z$ badaniami przeprowadzonymi w dniach 7-27 maja 2013 r., 83\% dorosłej populacji mieszkańców Autonomii Kraju Basków wyraża ogólnie negatywną ocenę bilansu działalności ETA w ciągu ostatnich czterdziestu lat, $7 \%$ - obojętną, $5 \%$ - pozytywną, a pozostałe $5 \%$ nie miało zdania, nie potrafiło lub nie udzieliło odpowiedzi. Rozkład szczegółowych postaw wobec ETA był następujący: pełna dezaprobata $-59 \%$, kiedyś tak, teraz nie $-16 \%$, cele tak, środki nie $-12 \%$, obojętność $-6 \%$, strach $-2 \%$, krytyczna akceptacja $-2 \%$, pełne poparcie $-1 \%$, brak odpowiedzi $-2 \%$. Badania przeprowadzone zostały na reprezentatywnej próbie dorosłych mieszkańców Autonomii Kraju Basków, $n=1200$, na którą składały się trzy grupy $(n=400)$ z każdej $z$ trzech prowincji, tj. Araba, Gipuzkoa, Bizkaia (są to nazwy baskijskie, w języku kastylijskim odpowiednio: Álava, Guipúzcoa, Vizcaya) (Euskobarómetro 2013).
} 
panii, z prymatem centralizacji, popartą wyobrażeniem o homogenicznym charakterze narodu hiszpańskiego, co miało zyskiwać przełożenie na osiągnięcie jednolitości w kategoriach etnicznych, kulturowych, a zarazem językowych. Euskera należał do elementów zakłócających spójność oficjalnej ideologii, a chęć posługiwania się nim podważała wizję jednego narodu hiszpańskiego. Kwalifikowany był jako „element egzotyczny” — wymagający wyplenienia, a w żadnym razie nie ochrony.

Odmienność językowa była zarazem czynnikiem wykluczającym tych, dla których był to jedyny język, jakim byli w stanie się posługiwać. Działo się tak choćby ze względu na pragmatykę funkcjonowania w sferze publicznej, w której obowiązywał wyłącznie język kastylijski. Dotyczyło to też tych, którzy znali kastylijski, ale euskera uznawali za swój język ojczysty i byli oporni na zabiegi asymilacyjne. Ponieważ jednak w życiu publicznym obowiązywał język kastylijski, część Basków nie tylko dostosowała się do wymogu, ale i zatraciła znajomość języka przodków. Polityka władz centralnych wobec euskera za czasów reżimu frankistowskiego doprowadziła wprawdzie do zaprzepaszczenia jego znajomości przez część populacji, ale przyniosła także efekt odwrotny. Była mianowicie czynnikiem niepomiernego zwiększenia jego politycznej wagi, a także umocnienia jego związku z tożsamością etniczną oraz światopoglądem politycznym. Nauczanie euskera nabrało wymiaru deklaracji ideowej. Tradycyjnie w Baskonii istniały placówki prowadzące nauczanie dzieci w euskera o nazwie ikastola/ $-k^{7}$, ale w czasach sprawowania władzy przez generała Franco działały one na początku nielegalnie, będąc przedmiotem starań działaczy lokalnych oraz kleru. Wbrew temu, co twierdzi Wolfgang Jütte (2000, s. 153), przypisując pierwszy etap ich działania na lata 1943-1960, były one obecne $\mathrm{w}$ życiu społecznym znacznie wcześniej i jest to udokumentowane $\mathrm{w}$ literaturze (Goenaga 2004; Pablo [de] 1994; López Atxurra 1995). Ich powstanie nie było w żadnym razie reakcją na wprowadzenie reżimu generała Franco. Jak podaje Patxi Goenaga (2004, s. 121), pierwsza ikastola powstała w mieście San Sebastian ${ }^{8}$, dzisiejszej stolicy prowincji Bizkaia, i było to jeszcze na

\footnotetext{
${ }^{7}$ Forma w liczbie pojedynczej w euskera to ikastola, w liczbie mnogiej to ikastolak. Ponieważ termin ten został przyjęty w odniesieniu do szkół prowadzących nauczanie w języku Basków w Hiszpanii, zaadaptowano go też w liczbie mnogiej w języku kastylijskim zgodnie $z$ zasadami słowotwórstwa tego języka jako ikastolas i w takiej formie występuje w literaturze $z$ zakresu nauk społecznych w tym języku, a także - z tego samego powodu — w cytowanych pracach w języku angielskim. Dalej w tekście posługuję się tym pojęciem, wprowadzając odmianę przez przypadki zgodną z zasadami języka polskiego.

8 Baskijska nazwa tego miasta to Donostia. Dla porządku dodaję, że właśnie tą nazwą posługuje się w swej książce Goenaga (2004, s. 121). W dzisiejszej Hiszpanii stosuje się też nazwy dwujęzyczne, z nazwą w języku kastylijskim połączoną z obowiązującą $\mathrm{w}$ euskera. Trzymając się tego przykładu - będzie to San Sebastián-Donostia, ewentualnie w odwrotnej kolejności i/lub z ukośnikiem $w$ zapisie, co jest uzusem często stosowanym $w$ celach administracyjnych. W przeciwieństwie do treści tego przypisu, w tekście zasadniczym posługuję się celowo nazwą San Sebastian bez akcentu, zgodnie $z$ tym, jak jest ona przyjęta w języku polskim.
} 
długo przed epoką frankizmu, to jest w 1914 roku. Ich liczba rosła i aktywnie działały na rzecz zachowania spuścizny językowej ludności autochtonicznej. W 1932 roku powstało skupiające je zrzeszenie, zwane Eusko-Ikastola Batza, czyli Federacja Szkół Baskijskich. Fakt ten odnotowuje zarówno Santiago de Pablo (1994, s. 31), jak i Rafael López Atxurra (1995, s. 10). Według Lópeza Atxurri Federacja obejmowała czternaście ikastoli, z czego dwanaście w prowincji Bizkaia i jedna placówka tego typu w mieście Bergara, znajdującym się w prowincji Gipuzkoa. Miały one charakter wyznaniowy i podtrzymywały jak twierdzi - baskijskie imaginarium nacjonalistyczne. Ponadto istniało dwanaście niezrzeszonych ikastoli w Gipuzkoa. Autor ten dokumentuje też istnienie kilku ikastoli w poszczególnych miastach Kraju Basków oraz w Nawarze, zakładanych na początku lat trzydziestych. Chociaż po hiszpańskiej wojnie domowej — jak podkreśla de Pablo (1994, s. 31) — zakazano działalności ikastoli, część placówek kontynuowała nauczanie, również w postaci odbywających się $\mathrm{w}$ prywatnych domach tajnych kompletów. Inicjatywa tajnego nauczania euskera była utrzymywana przynajmniej od 1943 roku, najprawdopodobniej po przerwie związanej z hiszpańską wojną domową i okresem surowych represji powojennych. Doniosły udział w tych poczynaniach miała postępowa baskijska pedagog i znana działaczka na rzecz nauki euskera Elbira Zipitria Irastorza ${ }^{9}$. Niektóre $z$ tych placówek funkcjonowały w domach lub miały lokalizacje związane $z$ Kościołem, jak choćby ikastola założona właśnie przez Zipitrię w latach 1952-1953 w zakonie benedyktynów (López Atxurra 1995, s. 12). Wraz z odwilżą polityczną w schyłkowym okresie rządów Franco rósł poziom przyzwolenia dla instytucji zakładanych w celu kultywowania dziedzictwa językowego Basków. Momentem kluczowym dla podtrzymania znajomości euskera i baskijskiej tożsamości w lokalnych społecznościach było powstanie w 1969 roku federacji ikastoli o nazwie Gipuzkoako Ikastolen Federazioa, znanej też pod nazwą kastylijską jako Federación Diocesana de Ikastolas. Zrzeszała ona aż 86 ikastoli, prowadzących nauczanie euskera dla ponad ośmiu tysięcy uczniów (López Atxurra 1995, s. 16). Założono ją jako organizację wyznaniową, ale po blisko dziesięciu latach uległa ona przekształceniom i zyskała charakter świecki. Objąwszy swą misją również zwiększenie alfabetyzacji dorosłych, placówki zajmujące się kultywowaniem baskijskiego dziedzictwa językowego pełniły ponadto funkcję tak zwanych gaueskoli, o których mowa dalej.

Jak wskazuje Montserrat Guibernau (2006, s. 70), wymogi asymilacji i surowe traktowanie Basków, podobnie zresztą jak - będących głównym przedmiotem jej zainteresowania - Katalończyków, nie tylko nie przyniosły sukcesu, ale wręcz doprowadziły do przeciwnych rezultatów. Chodzi po pierwsze o konsolidację oporu wobec reżimu i wzmocnienie poczucia wspólnoty wśród mniejszości, a po drugie o zaostrzenie podziału w życiu społecznym: na sferę

\footnotetext{
${ }^{9}$ Jest to baskijski zapis jej imienia. Znana jest też jako Elvira Zipitria (ta wersja jej imienia i jedno nazwisko podawane są w cytowanej literaturze).
} 
publiczną i prywatną, w której można było podtrzymywać swą kulturę i posługiwać się własnym językiem. Funkcjonowanie ikastoli, podobnie jak samą naukę euskera za czasów reżimu określano mianem działalności antyfrankistowskiej (Lasagabaster Herrarte 2008, s. 140). Jednak długoletnia polityka centralizacyjna gabinetu Franco nie tylko nie doprowadziła do wyplenienia języka Basków, ale sprawiła, że świadomość językowa nabrała wyraźnego charakteru politycznego oraz wiązała się z poczuciem, że mówiący w tym języku stanowią odrębny - nieuznawany przez oficjalne władze - naród baskijski. Nawet prowadzenie prywatnej rozmowy w euskera na ulicy nabrało wymiaru deklaracji ideowej. Popularyzacja form językowych w tym języku dodawanych podczas standardowej rozmowy po kastylijsku na przywitanie oraz pożegnanie (np. odpowiednio: kaixo i agur) była interakcyjnym potwierdzeniem tożsamości baskijskiej, wyrazem sprzeciwu wobec opresyjnego systemu i sposobem poparcia dążeń niepodległościowych na poziomie codzienności (Gatti 2007, s. xv). Euskera był niedozwolony w życiu publicznym, ale krótkie przywitanie w tym języku łatwo mogło ujść uwadze niepowołanego słuchacza. Stosowanie wbrew reżimowi generała Franco baskijskich form przywitalnych i pożegnalnych stanowi przykład zjawisk mieszczących się w kategorii, którą Michael Billig (2008) nazywa banalnym flagowaniem przynależności narodowej ${ }^{10}$. Chodzi mianowicie o przypominanie, utrwalanie czy rekonstruowanie poczucia wspólnoty narodowej, a tym samym jego naturalizowanie poprzez symbole, zwroty, przysłowia, pieśni, stosowanie określenia „my” czy „nasz naród”, nie tylko przez polityków, ale również - co dotyczy omawianego przypadku w codziennych interakcjach między ludźmi.

Euskera za rządów generała Franco nie został całkowicie wyeliminowany z życia społecznego. Działo się wręcz przeciwnie i nie zanikły sposoby podtrzymywania jego znajomości w baskijskich społecznościach, na początku pozalegalne, które w końcu, w ostatniej dekadzie frankizmu, zostały zaakceptowane jako niedogodny systemowo, ale niemożliwy do wyeliminowania fakt społeczny. Rząd poszedł na ustępstwo i dopuścił formalizację działania ikastoli. Schyłkowy okres frankizmu naznaczyła odwilż, zarówno pod względem rezygnacji z autarchii jako ideału funkcjonowania państwa hiszpańskiego i stopnio-

10 Atrybut „narodowy” w odniesieniu do tego zjawiska jest zasadny, po pierwsze, zważywszy na pierwotne szerokie rozumienie narodu zgodnie ze znaczeniem lacińskiego natio, które odparte jest na urodzeniu, a zatem wspólnych korzeniach, bez wymogu, aby miały przełożenie na naród jako kategorię formalnoprawną. Po drugie, wśród Basków, zwłaszcza opowiadających się za secesją, istnieje przekonanie o tym, że stanowią odrębny naród. Należy podkreślić, że w kategoriach legislacyjnych Baskowie nie stanowili narodu ani w Hiszpanii frankistowskiej, ani współcześnie go nie stanowią. Zgodnie z przyjętą podczas procesu transformacji systemowej i obowiązującą do dziś Konstytucją Hiszpanii z 1978 roku w kraju tym istnieje jedynie suwerenny oraz niepodzielny n a ró d hiszpański, na który składają się, niewyszczególnione zresztą w ustawie zasadniczej, różne n a r o d ow ości - w rozumieniu formalnoprawnym jedynie wśród tych ostatnich mogą lokować się Baskowie. 
wego otwierania się Hiszpanii na świat zewnętrzny w zakresie stosunków politycznych, gospodarczych i w szeroko rozumianym kontekście cywilizacyjnym, jak i większej akceptacji zróżnicowania kulturowego wewnątrz kraju ze strony władz centralnych. Ikastole, wcześniej istniejące w ukryciu, zyskały formę prawną jako placówki nauczające euskera, aby wraz z procesem transformacji demokratycznej zostać uznane za część systemu edukacyjnego. Dopuszczono też nauczanie euskera na kursach dla dorosłych w specjalnie w tym celu prowadzonych i funkcjonujących do dnia dzisiejszego szkołach wieczorowych, zwanych gaueskolas (Amorrortu 2003, s. 41). Początkowo były to formy oddolne, o prostym kształcie organizacyjnym, pozbawione prawnego umocowania. Wraz z ikastolami dały początki zaawansowanej strukturze, na którą współcześnie składa się cała sieć, zarówno wspierana przez rząd na poziomie autonomicznym, jak i — zgodnie z prawem — dysponująca wsparciem władzy centralnej.

\section{POSTAWA FRANCO WOBEC KOŚCIOŁA A ZMIANA KLIMATU MORALNEGO WŚRÓD KLERU}

Na rzecz idei narodowej i centralizacji politycznej państwa Kościół w Hiszpanii od wieków działał $\mathrm{w}$ sposób systematyczny, ciesząc się silną pozycją w relacjach z władzą świecką. Również za czasów frankizmu miał status uprzywilejowany i - ogólnie rzecz biorąc - stał po stronie reżimu. Idea narodowa oraz wiara były elementami niezmiennie idącymi w parze. Jak podkreśla Guibernau (2006, s. 72), naród i kultura były utożsamiane $z$ katolicyzmem oraz tradycją, a jakakolwiek odmienność względem nich nie znajdowała miejsca w wyraźnie zarysowanych ramach systemowych. Naród traktowany był jako byt homogeniczny, bez uwzględnienia różnorodności kultur, języków, a także genealogii i historycznych losów jego części składowych. Wiara katolicka miała stanowić dla nich łącznik, a instytucja Kościoła we współpracy z rządem — stać na straży moralności hiszpańskich obywateli, nie tylko w sferze obyczajowej, ale również w odniesieniu do kwestii światopoglądowych.

Przede wszystkim jednak to sam generał Franco opowiadał się jednoznacznie po stronie Kościoła. Zgodnie z jego wyobrażeniami i oficjalną retoryką Hiszpania miała stać się Una, Grande y Libre, czyli ,jedna ${ }^{11}$, wielka i wolna” pod względem nie tylko politycznym i gospodarczym, ale i kulturowym. W monumentalnych planach, jakie kreślił dla państwa hiszpańskiego, słowem kluczowym była unidad, czyli właśnie „jedność”, i to zarówno religijna, społeczna, jak i polityczna, która - zgodnie z jego wyobrażeniami — miała być gwarantem pokoju, wielkości Hiszpanii i wolności.

\footnotetext{
$11 \mathrm{~W}$ swobodnym tłumaczeniu tej dewizy na język polski wyraz una bywa tłumaczony jako „zjednoczona”, co nieco zręczniej brzmi w odniesieniu do państwowości w języku polskim. De facto zjednoczona to $\mathrm{w}$ języku kastylijskim unida. Co więcej, w retoryce frankistowskiej chodzi o Hiszpanię jako jeden byt społeczno-polityczny, co ważne — o charakterze substancjalnym.
} 
Do realizacji ideałów miały się przyczynić elementy takie jak narzucenie kastylijskiego — zwanego hiszpańskim — jako języka obowiązującego w sferze publicznej, a także łączące obywateli kraju od wieków jedno wyznanie i instytucja Kościoła. Oczekiwania wobec obywateli dotyczyły pełnej zgody w zakresie tożsamości hiszpańskiej, moralności opartej na zaleceniach Kościoła, a ponadto poglądów nie odbiegających od wyznaczonych przez ramy systemowe oraz działań politycznych w pełni zgodnych z tym, czego żądają władze. Generał Franco promował ideę narodu hiszpańskiego podpartego katolicyzmem w sposób nad wyraz konsekwentny (por. Casanova 2009, s. 10; Cárcel Ortí 2002). Generalnie rzecz biorąc, związek narodu i wiary znajdował analogię w życiu instytucjonalnym, to jest we wzajemnym poparciu między władzą świecką a Kościołem. Przynajmniej w oficjalnie wyrażanej postawie Franco był propagatorem nie tyle ich pragmatycznych relacji, ile władzy świeckiej podpartej gorliwą wiarą i rewerencją względem Kościoła. Wytrwał przy tym przez cały okres sprawowania rządów. W przykładowym orędziu świątecznym wygłoszonym w 1972 roku, które cytuje Vicente Cárcel Ortí (2002, s. 233), explicite wyrażał taki właśnie stosunek wobec Kościoła, łącząc go z gotowością do współpracy oraz deklaracjami głębokiej wiary, które wielokroć towarzyszyły jego oficjalnym wypowiedziom. Mówiąc o kwestiach moralnych w imieniu hiszpańskiego rządu - nota bene stosował przy tym zabieg retoryczny polegający na posługiwaniu się liczbą mnogą — dodał, że „wszystkie podejmowane wcześniej oraz obecnie działania w służbie Kościoła wykonujemy zgodnie z tym, co dyktuje nam nasze chrześcijańskie sumienie, bez poszukiwania poklasku czy uznania" (Cárcel Ortí 2002, s. 233) ${ }^{12}$.

Postawa Franco wobec Kościoła nie uległa zmianie nawet wówczas, gdy w niektórych środowiskach kościelnych zaczęły pojawiać się symptomy adaptacji do zachodzących od lat sześćdziesiątych przemian społeczno-gospodarczych oraz poparcie wobec zmian politycznych w Hiszpanii (por. Cárcel Ortí 2002, s. 233; Casanova 2009, s. 11). W sposób niewzruszony podpierał się wiarą w Boga i odwoływał do autorytetu Kościoła, natomiast w sferze życia społeczno-politycznego zaczął przystawać na pewne zmiany. Pod koniec sprawowania władzy w swych orędziach deklarował nawet, że porządek polityczny jest otwarty, dynamiczny i cechuje go potencjał innowacyjności ${ }^{13}$. Z szeroko zakrojonymi przemianami społeczno-gospodarczymi oraz otwarciem się Hiszpa-

\footnotetext{
12 Tekst oryginalny: „Todo cuanto hemos hecho y seguiremos haciendo en servicio de la Iglesia, lo hacemos de acuerdo con lo que nuestra consciencia christiana nos dicta, sin buscar el aplauso ni siguiera el agradecimiento" (tłum. własne).

13 Orędzia noworoczne generała Franco od lat trzydziestych — niemal z wszystkich lat — aż do ostatniego, wygłoszonego 12 grudnia 1974 r. umieszczone są w wolnym dostępie na następującej stronie internetowej: http://www.generalisimofranco.com/Discursos/MENSAJES/00000.HTM. Jest to strona adresowana do zwolenników generała i umieszczono na niej — poza materiałami archiwalnymi - artykuły o charakterze ideologicznym. Pod linkiem, który podaję, znajduje się wykaz jego orędzi noworocznych z oryginalną treścią. Do zmian dyskursywnych w wypowiedziach
} 
nii na świat szła w parze liberalizacja systemowa. $Z$ czasem przyszło osłabienie rygoru politycznego. Przełożyło się to na wiele kwestii społecznych, również na to, że kler coraz bardziej otwarcie był bliżej ludu.

Manuel Ortiz Heras (2005, s. 162) pisze wręcz o przechodzeniu środowisk kościelnych ku postawie opozycyjnej, dysydenckiej, a w łagodniejszej wersji choćby kompromisowej względem frankizmu, w miejsce relacji symbiotycznej i współdziałania. Co więcej, zmiana klimatu moralnego w postaci stopniowego odsuwania się od frankizmu miała przełożenie na coraz większe przyzwolenie Kościoła dla działań poszczególnych parafii w Kraju Basków na rzecz prowadzenia nauczania w euskera. Jak staram się wykazać, dla roli Kościoła i jego postawy wobec odmienności baskijskiej charakterystyczny był pewien paradoks. Z jednej strony Kościół w Hiszpanii na poziomie centralnym zasadniczo stał po stronie reżimu generała Franco, a $z$ drugiej strony środowiska kościelne na poziomie lokalnym - przy coraz większym przyzwoleniu zwierzchników lub choćby przymykaniu oka - wspierały wśród Basków edukację w języku ich przodków.

\section{IKASTOLA I ROLA KOŚCIOŁA WOBEC BASKIJSKIEJ ODMIENNOŚCI JĘZYKOWEJ}

Generalnie rzecz biorąc, za czasów generała Franco Kościół zapewniał rządowi Hiszpanii moralną oraz instytucjonalną podporę zabiegów centralizacyjnych, zwłaszcza przez kształtowanie w zróżnicowanym etnicznie społeczeństwie idei jednego narodu hiszpańskiego. Elementem sprzyjającym unifikacji było nie tylko wspólne wyznanie, które już od wieków łączyło Hiszpanów, ale i wspólny język kastylijski, również dziś zwyczajowo nazywany językiem hiszpańskim. Autorzy prac na temat frankizmu jednoznacznie odnoszą się do roli Kościoła w zakresie poparcia idei centralizacji kraju oraz unifikacji narodowej, mniej znana jest natomiast kwestia obosieczności działań instytucji Kościoła w tym zakresie. Chodzi mianowicie o wspieranie poczucia baskijskiej odrębności etnicznej, do czego przyczyniał się Kościół na poziomie lokalnym poprzez promowanie, finansowanie i organizowanie nauki języka przodków w parafiach — obok indywidualnie prowadzonych kompletów - w takim zakresie, w jakim dopuszczał to reżim. Interesującą tezę, wcale nie sprzeczną z proponowanymi przeze mnie na koniec wyjaśnieniami, wysuwa w swej kontrowersyjnej pracy César Vidal (2014), odnosząc ją do szeroko traktowanej polityki językowej Kościoła Hiszpanii w związku z jego stosunkiem wobec rządu. Uważa mianowicie, że intensywne poparcie, którym Kościół darzył za czasów Franco, a także wcześniej, nauczanie języków regionalnych w Hiszpanii stanowiło instrument osłabiania pozycji władzy świeckiej. Vidal nie dostarcza dowodów, że takie były zamiary ze strony Kościoła, z pewnością jednak osłabienie władzy centralnej

Franco odnoszę się jedynie sygnalnie. Istotny jest tu ogólny klimat odwilży politycznej z uwagi na pojawienie się możliwości wspierania przez kler nauki euskera w Kraju Basków. 
stanowiło jeden $\mathrm{z}$ rezultatów prowadzonej przez kler pracy u podstaw społeczności baskijskich.

Ważnym czynnikiem wspierania przez Kościół baskijskiej odrębności, nie uwzględnionym we frankistowskim imaginarium, była silna wiara katolicka wśród samych Basków, podparty nią kapitał społeczny, w tym zaufanie do choćby części kleru oraz istniejąca od dawien dawna infrastruktura kościelna na poziomie lokalnym. Zgodnie z danymi Lópeza Atxurry (1995, s. 1), od XVI do XVIII wieku katechizację prowadzono w euskera. Jest prawdopodobne, że dotyczyło to części kościołów lub poszczególnych mszy, jednak fakt ten wyraźnie wskazuje na długą tradycję podtrzymywania przez kler lokalnego języka. Trudno byłoby zatem oczekiwać, aby wszyscy księża, w tym ci o baskijskiej identyfikacji, działali w pełni na rzecz centralistycznych założeń i jednomyślnie pracowali $\mathrm{w}$ celu wykorzenienia własnego języka, traktując go — zgodnie $z$ wolą Franco - jako obcy element. Nic dziwnego, że część z nich wspierała naukę euskera $\mathrm{w}$ parafiach czy domach prywatnych, tak jak już w początkach $\mathrm{XX}$ wieku, długo zanim dyktator doszedł do władzy. Warto przywołać fakt, na który zwraca uwagę Guibernau (2006, s. 71) w kontekście relacji między Kościołem a reżimem generała Franco. Podczas gdy Kościół generalnie opowiadał się po stronie frankizmu, na poziomie lokalnych środowisk kościelnych w Kraju Basków, a także w Katalonii, na której koncentruje swe zainteresowania ta autorka, istniały kręgi podważające takie stanowisko wobec władzy centralnej. W obu regionach trwała tradycja wiążąca $z$ pewnymi segmentami środowiska kościelnego tak zwany w hiszpańskiej socjologii p e ry fe ryj n y nacjo n al i z m (np. Gurruchaga 1985; s. 19; Enguita 2003, s. 9; Moreno Cabrera 2007, s. 381; Pérez-Agote 2008, s. 45), oparty na idei narodu odnoszącej się do poszczególnych mniejszości etnicznych w kraju i dotyczący zamieszkiwanych przez nie terenów (Guibernau 2006, s. 71). W bardziej radykalnej politycznie wersji wyrażały one poparcie wobec dążeń niepodległościowych lokalnej ludności lub - co nie mniej istotne - zapewniały oparcie w codziennych dążeniach do zachowania odrębności etnicznej, w tym do nauki prowadzonej w euskera.

$\mathrm{Na}$ fakt wspierania przez Kościół nauczania w tego rodzaju placówkach zwraca uwagę wielu autorów (Clark 1979, s. 147; Williams 1984, s. 204; Lasagabaster Herrarte 2008, s. 140; Placer Ugarte 2010, s. 154; Vidal 2014; Shafir 1995, s. 119). Poza precedensem, jakim było uznanie w 1965 roku istnienia jednej ikastoli w Bilbao - co miało stanowić element pokazowy otwartości władz centralnych na odmienność - oficjalnie na hiszpańskich terenach Baskonii w tym okresie takich placówek nie było. W rzeczywistości jednak, podobnie jak wcześniej, istniały i prowadzone były zazwyczaj albo w zaciszu domów prywatnych, albo — również pozalegalnie - w pomieszczeniach parafialnych. Było tak aż do 1968 roku, gdy zalegalizowano dekretem fakt ich istnienia. Dokument ów nie kwalifikował wprawdzie ikastoli jako jednostek w ramach systemu szkolnictwa, zapewniał jednak możliwość ich rejestrowania i pozostawania w gestii podmiotów pozapaństwowych, w tym przede wszystkim parafii i zakonów. Taka 
kwalifikacja prawna była posunięciem zasadnym ze strony władz, zwłaszcza że wcześniejsze ich funkcjonowanie w wielu przypadkach fundowane było albo przez osoby prywatne, albo przez Kościół. Ander Gurruchaga (1985, s. 263) nazywa wręcz instytucję Kościoła „parasolem ochronnym” dla nauczania euskera. Do konkretnego przypadku odwołuje się w biograficznym kompendium na temat postaci znaczących dla historii Kraju Basków Iñaki Egaña (2005, s. $11^{14}$ ), odnotowując fakt istnienia ikastoli prowadzonej w Donostii od 1951 roku przez osobę prywatną - najpierw nielegalnie w warunkach domowych, a wraz ze zmianami legislacyjnymi z roku 1968 jako placówka pod auspicjami Kościoła, na której podstawach powstała wreszcie znacząca w tym mieście ikastola Orixe. Wiele podobnych przypadków odnotowuje Félix Luengo (2001, s. 439).

Można $\mathrm{w}$ sposób zasadny argumentować, że znaczącym czynnikiem promowania nauki euskera przez kler na poziomie lokalnym była mocna pozycja wyznania oraz instytucji Kościoła wśród Basków. Ponieważ w baskijskich społecznościach od dawna obserwowano wysoki poziom religijności, a także głębokie poszanowanie tradycji, nieuwzględnianie na poziomie lokalnym znaczenia tej spuścizny oraz języka przodków byłoby elementem zniechęcającym do instytucji Kościoła i zmniejszającym partycypację religijną, stanowiłoby zatem dla Kościoła rozwiązanie niekorzystne instytucjonalnie. Nie bez znaczenia pozostaje fakt, że w środowiskach kościelnych były osoby pochodzące $z$ lokalnych społeczności i związane z nimi, a nie jedynie przyjezdni księża. Były one nosicielami kultury baskijskiej, zainteresowanymi jej trwaniem tak samo jak podlegający im parafianie. Dodatkowym argumentem jest to, że w tamtym okresie, przy niskim poziomie scholaryzacji, hermetyczności lokalnych wspólnot i tradycyjnym, wiejskim życiu, dla części starszej i mniej wykształconej ludności lokalnej - mimo zabiegów na rzecz unifikacji systemu kształcenia - euskera pozostawał jedynym językiem, w którym potrafili się sprawnie porozumiewać. W takich warunkach zasadne było prowadzenie działalności edukacyjnej na podstawowym poziomie i zwiększanie alfabetyzacji właśnie w ich języku.

Nauka i codzienne użycie euskera stanowiły dla Basków, i w dalszym ciągu stanowią, główny instrument starań o zachowanie odrębności etnicznej. Właśnie ikastole pełniły kluczową rolę w zachowaniu baskijskiej tożsamości. W czasach frankizmu odbywało się to przy znaczącym udziale kleru. Zgodnie z danymi podawanymi przez Fernando Gonzáleza Ollé (2008, s. 544) w 1975 roku, czyli w roku śmierci generała Franco, było aż 122 ikastole. Niestety, nie podaje on informacji, czy była to łączna ich liczba na obecnym terenie

14 Chodzi o ikastolę prowadzoną przez mieszkankę Donostii Faustinę Carril Arozenę (1912-1997) wraz z wspomnianą wcześniej Elvirą Zipitrią (1906-1982) pod auspicjami tamtejszego kościoła św. Marii. 
Autonomii Kraju Basków, czy też obejmowała ona również placówki funkcjonujące na obszarze Nawarry, która także stanowi dziś wspólnotę autonomiczną (i której warto poświęcić odrębną pracę na temat tożsamości i języka). Można jedynie domniemywać, że dane podane przez Gonzáleza Ollé dotyczą wszystkich ikastoli na terenie Hiszpanii, zważywszy że mieszczące się w granicach tego państwa tereny historycznej krainy Baskonii nie były jeszcze w ten sposób podzielone administracyjnie. Zmiany, jakie nastąpiły w Hiszpanii po transformacji systemowej, były radykalne również w odniesieniu do języków regionalnych. Choć obowiązująca współcześnie Konstytucja nie dopuszcza uzyskania suwerenności przez żadną z Autonomii, ich języki rdzenne zaliczane są zgodnie $z$ literą prawa do dziedzictwa kulturowego kraju i podlegają ochronie - choć jej zakres znacząco zmienia się przy każdej zmianie rządzącego gabinetu.

\section{BIBLIOGRAFIA}

Amorrortu Estibaliz, 2003, Basque Sociolinguistics: Language, Society, and Culture, University of Nevada Press, Center for Basque Studies, Reno, NV.

Azurmendi María-José, Bachoc Erramun, Zabaleta Francica, 2001, Reversing Language Shift: The Case of Basque, w: Joshua A. Fishman (red.), Can Threatened Languages Be Saved? Reversing Language Shift Revisited. A $21^{\text {st }}$ Century Perspective, Multilingual Matters Ltd., Clevedon-Tonawanda, NY-North York, Ontario.

Billig Michael, 2008, Banalny nacjonalizm, tłum. Maciek Sekerdej, Znak, Kraków.

Cárcel Ortí Vicente, 2002, Historia de la Iglesia en la España contemporánea: Siglos XIX y XX, Ediciones Palabra S.A., Madrid.

Casanova Julián, 2009, La Iglesia de Franco, Crítica S.L., Barcelona.

Clark Robert P., 1979, The Basques, the Franco Years, and Beyond, University of Nevada Press, Reno, NV.

Conversi Daniele, 1997, The Basques, the Catalans and Spain: Alternative Routes to Nationalist Mobilisation, University of Nevada Press, Reno, NV.

Echeverria Begoña, 2007, Learning and Working in Basque: Implications for Basque Identity, w: Katherine Schuster, David Witkosky (red.), Languages of the Land. Policy, Politics, Identity: A Volume in Studies in the History of Education, Information Age Publishing, Charlotte NC.

Egaña Iñaki, 2005, Diccionario histórico-político de Euskal Herria, Txalaparta S.L.L., Tafalla, Nawarra. Enguita Mariano Fernández, 2003, Presentación, w: Francisco J. Llera, Fernando Savater, Joseba Arregi, Antonio Elorza (red.), Nacionalismo y democracia, Ediciones Universidad de Salamanca, Salamanca.

Gatti Gabriel, 2007, Identidades débiles. Una propuesta téorica aplicada al estudio de la identidad en el País Vasco, Centro de Investigaciones Sociológicas, Madrid.

Goenaga Patxi, 2004, Fronteras que dividen y fronteras que separan. Una mirada a Europa desde el Euskara, w: Joan A. Argenter, R. McKenna Brown, Proceedings of the $8^{\text {th }}$ FEL Conference, The Foundation of Endangered Languages, 1-3 października 2004, Barcelona.

Guibernau Montserrat, 2006, Catalan Nationalism and the Democratization Process in Spain, w: Karl Kordell (red.), Ethnicity and Democratisation in the New Europe, Routledge, New York.

Gurruchaga Ander, 1985, El código nacionalista vasco durante el franquismo, Anthropos, Editorial del Hombre, Barcelona.

Haasse Martin, 2011, Basque, w: Bernd Kortmann, Johan van den Auwera (red.), The Languages and Linguistics of Europe: A Comprehensive Guide, Walter de Gruyter, Boston-Berlin. 
Ibarretxe Gozton, Larrea Kepa, 2012, Basque Diction, w: Duane Richard Karna (red.), The Use of the International Phonetic Alphabet in the Choral Rehearsal, The Rowman \& Littlefield Publishing Group-Scarecrow Press, Plymouth.

Jütte Wolfgang, 2000, Language Policy and Adult Education in Multilingual States as a Difficult Liason: The Case of Spain, w: Agnieszka Bron, Michael Schemmann (red.), Language - Mobility - Identity: Contemporary Issues for Adult Learning in Europe, LIT Verlag-Transaction Publishers-Rutgers University, Hamburg-Piscataway, NJ.

Kasmir Sharryn,1996, The Myth of Mondragón: Cooperatives, Politics, and Working-class Life in a Basque Town, State University of New York Press, Albany, NY.

Lasagabaster Herrarte Iñaki, 2008, La represión de los nacionalismos históricos, w: Federico Fernández-Crehuet López, António Manuel Hespanha (red.), Das Europa der Diktatur. Franquismus und Salazarismus. Legitimation durch Diktatur, Vittorio Klostermann GmbH, Frankfurt am Main.

López Atxurra Rafael, 1995, Cultura, educación y estudios vascos: hitos para la recuperación de nuestra memoria histórica, XII Congreso de Estudios Vascos. Estudios Vascos en el sistema educativo. Euskal Ikaskuntzak hezkuntza sarean, Eusko Ikaskuntza, Donostia.

Luengo Félix, 2001, En la memoria cercana 1936-2000, w: Miguel Artola (red.), Historia de Donostia-San Sebastián, Donostiako Udala-Editorial Narea, Donostia-San Sebastián-Hondarribia.

Mallea-Olaetxe Joxe, 2008, Speaking through the Aspens: Basque Tree Carvings in Nevada and California, University of Nevada Press, Reno, NV.

Mitxelena Koldo, 2001, Entre nosotros, Itxaropena-Alberdania S.L-Diputación Foral de Guipúzcoa, Irun.

Moreno Cabrera Juan Carlos, 2007, Nacionalismo lingüístico español, w: Carlos Taibo (red.), Nacionalismo español, esencia, memoria e instituciones, Los Libros de la Catarata, Madrid.

Ollé Fernando González, 2008, Identidad idiomática y política lingüística, w: Javier Elvira, Inés Fernández-Ordóñez, Javier García González, Ana Serradilla Castaño (red.), Lenguas, reinos y dialectos en la Edad Media ibérica. La construcción de la identidad, Iberoamericana-Vervuert, Madrid-Frankfurt am Main.

Ortiz Heras Manuel, 2005, Iglesia y control social: del controladora a controlada, w: Julio de la Cueva Merino, Ángel Luis López Villaverde (red.), Clericalismo y asociacionismo católico en España: de la restauración a la transición, Ediciones de la Universidad de Castilla-La Mancha, Cuenca.

Pablo (de) Santiago, 1994, Historia del nacionalismo vasco, 1876-1979, Fundación Sancho el Sabio, Vitoria-Gasteiz.

Placer Ugarte Félix, 2010, La Religión en Euskal Herria, Editorial Txalaparta S.L.L., Tafalla, Nawarra. Pérez-Agote Alfonso, 2008, Las raíces sociales del nacionalismo vasco, Centro de Investigaciones Sociológicas, Madrid.

Shafir Gershon, 1995, Immigrants and Nationalists: Ethnic Conflict and Accommodation in Catalonia, the Basque Country, Latvia, and Estonia, State University of New York Press, Albany, NY.

Trask Robert Lawrence, 1997, The History of Basque, Routledge, London-New York.

Vidal César, 2014, La historia secreta de la Iglesia católica en España, Ediciones B, S.A., Barcelona.

Williams Colin, 1984, More than Tongue Can Tell: Linguistic Factors in Ethnic Separatism, w: John Edwards (red.), Linguistic Minorities, Policies and Pluralism, Academic Press, London-Orlando, FL.

Zallo Ramón, 2006, Basques, Today: Culture, History and Society in the Age of Diversity and Knowledge, Alberdania S.L., Irun.

\section{Inne źrodła}

Constitución Española de 1978/Konstytucja Hiszpanii z 1978 roku, z dnia 31 października 1978 roku, ratyfikowana 6 grudnia 1978 roku, obowiązująca z dniem 29 grudnia 1978 roku, 
dokument dostępny online na stronie agendy rządowej BOE (Boletín Oficial de Estado) pod numerem 311 z 29/12/1978 (https://www.boe.es/buscar/act.php?id=BOE-A-1978-31229).

ES 2008, IV Encuesta Sociolingüística 2006, raport z badań, Departamento de Cultura, Servicio Central de Publicaciones de Gobierno Vasco, Vitoria-Gasteiz.

ES 2013, V Encuesta Sociolingüística 2011, raport z badań, Departamento de Educación, Política Lingüística y Cultura, Servicio Central de Publicaciones de Gobierno Vasco, Vitoria-Gasteiz.

Euskobarómetro 2013, Estudio periódico de la opinion pública vasca, maj 2013, raport z badań pod kierownictwem Francisco José Llera Ramo, Euskal Herriko Unibertsitatea [Uniwersytet Kraju Basków], Bilbao.

Strona internetowa: Generalísimo Francisco Franco (http://www.generalisimofranco.com/Discur sos/MENSAJES/00000.HTM [06.01.2015]).

\section{THE PARADOX OF IDENTITY POLICY IN FRANCO'S SPAIN: THE CHURCH'S AMBIVALENCE IN REGARD TO THE LINGUISTIC DISTINCTNESS OF THE BASQUES}

\section{Summary}

This article provides an analysis of the disparity between the Church's official position and its pragmatic activities in regard to the Basque minority in Spain under General Franco's regime. Linguistic distinctness has been a key factor enabling the Basque community to maintain its hermetic character and strong social ties in spite of systematic state-building measures based on the idea of a single Spanish nation. Contrary to general belief, the Church not only worked for but also against the national idea. The author argues that on the one hand it provided moral support for Spanish centralism and notions of a single nation and thus legitimized political activities aimed at assimilating the minority, but on the other hand, at the grassroots level in the Land of the Basques, it contributed to preserving the Basque language (the basis for maintaining ethnic distinctness and continuity), contrary to ideals of national unification.

\section{Key words / słowa kluczowe}

Spain / Hiszpania; Basques /Baskowie; Catholic Church / Kościół katolicki; ethnic minority (distinctness) / mniejszość (odrębność) etniczna; centralization / centralizacja 